\title{
Toxin content and cytotoxicity of algal dietary supplements
}

\author{
A.H. Heussner ${ }^{\text {a }}$, L. Mazija ${ }^{\text {a }}$, J. Fastner ${ }^{\text {b }}$, D.R. Dietrich ${ }^{\text {a,* }}$ \\ a Human and Environmental Toxicology, University of Konstanz, 78457 Konstanz, Germany \\ bederal Environmental Agency, Section 11 3.3-Drinking-water resources and treatment, Berlin, Germany
}

\section{Keywords:}

BCAS

Green algae

Microcystin

Saxitoxin

Anatoxin-a

cylindrospermopsin

\begin{abstract}
A B S T R A C T
Blue-green algae (Spirulina sp., Aphanizomenon flos-aquae) and Chlorella sp. are commercially distributed as organic algae dietary supplements. Cyanobacterial dietary products in particular have raised serious concerns, as they appeared to be contaminated with toxins e.g. microcystins (MCs) and consumers repeatedly reported adverse health effects following consumption of these products. The aim of this study was to determine the toxin contamination and the in vitro cytotoxicity of algae dietary supplement products marketed in Germany. In thirteen products consisting of Aph. flos-aquae, Spirulina and Chlorella or mixtures thereof, MCs, nodularins, saxitoxins, anatoxin-a and cylindrospermopsin were analyzed. Five products tested in an earlier market study were re-analyzed for comparison. Product samples were extracted and analyzed for cytotoxicity in A549 cells as well as for toxin levels by (1) phosphatase inhibition assay (PPIA), (2) Adda-ELISA and (3) LC-MS/MS. In addition, all samples were analyzed by PCR for the presence of the mcyE gene, a part of the microcystin and nodulatin synthetase gene cluster. Only Aph. flos-aquae products were tested positive for MCs as well as the presence of $m c y E$. The contamination levels of the MC-positive samples were $\leq 1 \mu g \mathrm{MC}$-LR equivalents $\mathrm{g}^{-1} \mathrm{dw}$. None of the other toxins were found in any of the products. However, extracts from all products were cytotoxic. In light of the findings, the distribution and commercial sale of $A p h$. flos-aquae products, whether pure or mixed formulations, for human consumption appear highly questionable.
\end{abstract}

\section{Introduction}

In the past decades organic algae dietary supplements consisting of cyanobacteria or green algae were increasingly consumed for their putative beneficial health effects. These supplements are marketed among other things for athletes, pregnant or breast-feeding women, vegetarians, and during times of stress and weight loss. They were also advertised as detoxifiers, energy sources or as mood improvers. In some instances, in the case of Aphanizomenon flos-aquae based cyanobacterial products, they were even marketed specifically for use in children, i.e. for the treatment of the Attention Deficit Hyperactivity Disorder. To date none of the beneficial effects could be scientifically and clinically confirmed. Moreover, the FDA mandated that companies selling cyanobacterial dietary supplements clearly state that these products have no pharmaceutical or curative capabilities: "This product is not intended to diagnose, treat, cure or prevent any disease".

Algae dietary supplements can be divided into three main groups: (1) Aph. flos-aquae, (2) Spirulina platensis and (3) Chlorella pyrenoidosa products.

The first group member is mainly harvested from an open environment, i.e. large lakes. The Upper Klamath Lake, Oregon, USA, is one of the most used sources for Aph. flos-aquae, where the toxic cyanobacterial

\footnotetext{
* Corresponding author at; Human and Environmental Toxicology, University of Konstanz, PO-Box: X-918, 78457 Konstanz, Germany. Fax: +497531883170 E-mail address: daniel.dietrich@uni-konstanz.de (D.R. Dietrich).
}

Microcystis aeruginosa occurs regularly and therefore can contaminate the products during harvesting. Indeed, an analysis of biomass from the harvest site published by Carmichael et al. (2000) demonstrated that $>80 \%$ of samples contained toxin (microcystin) values far exceeding the limit of $1 \mu \mathrm{g} M C-\mathrm{LR}_{\mathrm{eq}} \mathrm{g}^{-1} \mathrm{dw}$ that was established by the Oregon Department of Health (ODH) and the Oregon Department of Agriculture (ODA) for products containing blue-green algae (BGA) (Gilroy et al., 2000). Furthermore, Aph. flos-aquae itself has been shown to be able to produce toxins such as anatoxin-a (Rapala et al., 1993; Sieroslawska et al., 2010), saxitoxins (Ferreira et al., 2001; Mahmood and Carmichael, 1986; Zhang et al., 2012), BMAA (Cox et al., 2005) and cylindrospermopsin (Preussel et al., 2006; Stüken and jakobsen, 2010).

Spirulina, mostly originating from two filamentous genera of cyanobacteria, S. platensis and S. maxima (Belay et al., 1993, 1994), is commonly produced under cultured conditions and in open pond systems, where controlling growth of unwanted cyanobacterial species is attempted, but nevertheless contamination with toxins occurs (Jiang et al., 2008). Spirulina itself is generally considered to be non-toxic as to date no direct production of toxins was reported (Marles et al., 2011; Yang et al., 2011).

The green algae Chlorella is also cultivated in artificial ponds, where a contamination with other, potentially toxic organisms is not very likely. In the final products however, Chlorella is often mixed to varying proportions with other products such as Aph. flos-aquae, as can be observed from the varying products marketed on the internet. 
These algae dietary products are frequently consumed by humans in larger quantities and over longer periods of time, as suggested by the producers of these products, thereby inadvertently increasing the consumer's risk of a critical exposure to algae toxins and consequently potentially serious health effects. Indeed, according to the court hearing No. CV 08-3027-PA, United States District Court, District of Oregon. March 4, 2010 "U.S. v. KOLLMAN" (UNITED STATES OF AMERICA, Plaintiff, versus DARYL J. KOLLMAN, et al., Defendants), Cell Tech's (one of the major Aph. flos-aquae based dietary supplement companies on Klamath Lake) gross receipts were more than $\$ 193,000,000$ in 1996 , achieved via sales across the United States and Canada through 350,000 individual distributors.

As a consequence, several studies were conducted in the last years to determine the degree of toxin contamination of algae dietary supplements as well as to evaluate the potential risk associated with the consumption of these products. As had to be expected, microcystins (MCs) were repeatedly detected in Aph. flos-aquae products (Dietrich et al., 2008; Fischer et al., unpublished results; Gilroy et al., 2000; Hoeger et al., 2003; Saker et al., 2005, 2007; Vichi et al., 2012). However, only a very limited number of studies broadened their toxin analyses to include several different types of toxins. In view of the "contamination" problem of algae dietary products and the potential of Aph. flos-aquae to produce toxins by itself, a more in-depth understanding of the potential toxicities of algae dietary products is warranted. Indeed, the cyclic heptapeptide toxins (microcystins, MCs) are produced by several cyanobacteria including Anabaena and Planktothrix, whereas the pentapeptide cyclic toxins (Nodularins, Nod) are primarily produced by Nodularia (Pearson et al., 2010). Saxitoxin (STX) is a neurotoxin, known as a product of certain species of marine dinoflagellates, but also produced by freshwater cyanobacteria (Anabaena, Aphanizomenon, Cylindrospermopsis, Lyngbya, Planktothrix) (Clark et al., 1999; Landsberg, 2002; Pearson et al., 2010). Anatoxin-a (ATX) is a neurotoxic secondary, bicyclic amine alkaloid produced by at least four different genera of cyanobacteria (Ballot et al., 2010a, 2010b; Selwood et al., 2007). Cylindrospermopsin (CYN) is a toxic polycyclic uracil derivative produced by a variety of freshwater cyanobacteria, e.g. Aphanizomenon, which is a common genera in temperate lakes (Fastner et al., 2007; Pearson et al., 2010). Obviously, and based on above description of the potential toxin producers, algae dietary products could potentially be contaminated with all of the above toxins.

Consequently, we analyzed thirteen products of different brands available on the German market in 2010 consisting of Aph. flos-aquae, Spirulina and Chlorella for the presence of MC, STX, ATX and CYN using a protein phosphatase inhibition assay, ELISA, and LC-MS/MS. In addition, $\mathrm{PCR}$ analyses for $m c y \mathrm{E}$, part of the microcystin and nodularin synthetase gene cluster, allowed determination of the presence of the contaminant cyanobacteria possessing the mcyE gene. Finally, algae dietary product extracts were analyzed for general cytotoxicity in order to determine unspecified toxicity and thus interpret previous reports, e.g. by Health Canada (http://www.collectionscanada.gc.ca/webarchives/ 20071213074515/http://www.hc-sc.gc.ca/ahc-asc/media/nr-cp/1999/ 1999_114_e.html), on excessive diarrhea following ingestion of these algae dietary products.

\section{Materials and methods}

Materials. Unless stated otherwise, materials were purchased as follows: Abraxis, Warminster, PA, USA (ELISA kit, CYN standard), PAA Laboratories $\mathrm{GmbH}$, Cölbe, Germany (cell culture chemicals), Sarstedt, Nümbrecht, Germany (cell culture plastics), Waters GmbH, Eschborn, Germany (Sep-Pak\& Vac C18 cartridges), Enzo Life Sciences GmbH, Lörrach, Germany ([Asp $\left.{ }^{3}\right]-\mathrm{MC}-\mathrm{RR}, \mathrm{MC}-\mathrm{RR}, \mathrm{MC}-\mathrm{YR},\left[\mathrm{Asp}^{3}\right]-\mathrm{MC}-\mathrm{LR}$, MC-LR, MC-LW, MC-LF, MC-LA standards), DHI, Denmark (NOD standard), Tocris Bioscience, Bristol, UK (ATX standard), NRC, Ottawa, Canada (PSP standards) and Sigma-Aldrich $\mathrm{GmbH}$, Seelze, Germany (all other chemicals).

Algae dietary supplements. A total of eighteen products (Table 1) of different brands available on the German market were examined, whereby five of the samples had been tested in 2003-2008 and were reanalyzed for comparison. Of all products, ten consisted of Aph. flos-aquae (Aph\#01-09), five of S. platensis (Spir\#01-05) and three of $C$. pyrenoidosa (Chlo\#01-03).

The Aph. flos-aquae samples consisted of different brands and products with one exception, samples Aph\#01a and Aph\#01b were two different lots of the same product. Aph\#04(PC1) and Aph\#05(PC2) were products with a known high and moderate MC contamination, respectively (Hoeger et al., 2003). Aph\#06(NC1) was a product known to be free of MC contamination (Fischer et al., unpublished results). Thus Aph\#04(PC1) and Aph\#05(PC2), served as positive controls and Aph\#06(NC1) as a negative control in the analyses and functional assays. All products were blinded prior to extraction and subsequent analysis.

Preparation and purification of extracts from algae products. $375 \mathrm{mg}$ of each sample were mixed vigorously with $15 \mathrm{~mL} 75 \% \mathrm{MeOH}$. After application of ultrasound for $30 \mathrm{~min}$ (ice-cold), samples were centrifuged at $693 \times \mathrm{g}$ for $30 \mathrm{~min}$ at $\mathrm{RT}$. The supernatants were collected and stored on

Table 1

List of samples.

\begin{tabular}{|c|c|c|c|c|}
\hline Sample \# & Content & Producer & Exp. date & Lot\# \\
\hline Aphola & $94 \%$ Aph. flos-aquae & Wilco GmbH & $03 / 2013$ & $10592 A$ \\
\hline Aph01b & 94\% Aph. flos-aquae & Wilco GmbH & $03 / 2013$ & $10592 \mathrm{~B}$ \\
\hline Aph02 & Aph. flos-aquae & GSE-Vertrieb GmbH & $02 / 2012$ & L10592C_3161 \\
\hline Aph03 & Aph. flos-aquae & Hannes Pharma GmbH & $06 / 2012$ & $3-00-62-9$ \\
\hline Aph04 (PC01) & Aph. flos-aquae & Kid3.com & $05 / 2006$ & $100-020.114$ \\
\hline Aph05 (PCO2) & 94\% Aph. flos-aquae & Wilco GmbH & $03 / 2004$ & 20101 \\
\hline Aph06 (NC01) & Aph. flos-aquae & Keimling Naturkost $\mathrm{GmbH}$ & $06 / 2009$ & $\mathrm{C} 120770$ \\
\hline Aph07 & Aph. flos-aquae & Algavital VertriebsGmbH & $04 / 2004$ & K805 \\
\hline Aph08 & Aph. flos-aquae & Keimling Naturkost GmbH & $11 / 2011$ & No lot\# \\
\hline Aph09 & Aph. flos-aquae & Algavital VertriebsGmbH & $02 / 2012$ & AL1510 \\
\hline Spiro1 & Spirulina platensis & ALSTTA GmbH & $07 / 2012$ & PO-NN0320592A \\
\hline Spir02 & Spirulina platensis & Dr. Dünner AG & $06 / 2012$ & C94007 \\
\hline Spir03 & Spirulina & greenValley@ Naturprodukte $\mathrm{GmbH}$ & $09 / 2012$ & 19.09 \\
\hline Spir04 & Spinulina & lvarsson's Ltd. \& Co. KG & $09 / 2012$ & 01002151 \\
\hline Spir05 & Spirulina platensis $(78 \%)$ & Sanatur GmbH & $12 / 2011$ & 120296 \\
\hline Chlool & Chlorella pyrenoidosa (91\%), Aph. flos-aquae (9\%) & Bluegreen & 2012 & LNP033-1 \\
\hline Chlo02 & Chlorella & greenValley@ Naturprodukte GmbH & $07 / 2011$ & 15.02 \\
\hline Chloo3 & Chlorella pyrenoidosa & Taiwan Chlorella Manufacturing Co. & $07 / 2004$ & 7542 \\
\hline
\end{tabular}

a Only the lots indicated were tested, therefore no inference can be made with regard to the potential presence or absence of toxin contamination of other lots of the same product from the individual companies. 
ice. Pellets were re-suspended with $15 \mathrm{~mL} 75 \% \mathrm{MeOH}$ and the extraction procedure was repeated twice. The resulting supernatants were pooled and centrifuged at $2106 \times \mathrm{g}$ for $10 \mathrm{~min}$ at RT. Supernatants ( $45 \mathrm{~mL} / \mathrm{sample}$ ) were evaporated to dryness via vacuum centrifugation.

Dried extracts were re-suspended in $15 \mathrm{~mL}$ deionized water, vigorously mixed and sonicated for $15 \mathrm{~min}$ in an ice-cold ultrasound bath.

C18 solid phase extraction (SPE) was performed according to manufacturer"s instructions (Waters GmbH, Eschborn, Germany) in order to purify and concentrate MCs in the extracts. Briefly, the SPE columns were preconditioned with $100 \% \mathrm{MeOH}(2 \times 5 \mathrm{~mL})$ and equilibrated with deionized water $(2 \times 3 \mathrm{~mL})$. Extracts were applied and the SPE columns washed with deionized water $(3 \times 4 \mathrm{~mL})$. MC-elution was achieved with $100 \% \mathrm{MeOH}(3 \times 4.5 \mathrm{~mL})$. The collected eluates were evaporated to dryness via vacuum centrifugation. Dried extracts were re-suspended in $600 \mu \mathrm{L} 100 \% \mathrm{MeOH}$, vigorously mixed, sonicated for $7.5 \mathrm{~min}$ and $2400 \mu \mathrm{L}$ deionized water added. This mixture was sonicated and centrifuged at $13,000 \times \mathrm{g}$ for $20 \mathrm{~min}$ at $\mathrm{RT}$ to remove particles and extracts then stored at $-20^{\circ} \mathrm{C}$ until further analysis.

Colorimetric protein phosphatase inhibition assay (CPPIA). The CPPIA was performed according to Heresztyn and Nicholson (2001) with slight modifications. PP1 instead of PP2 was used with a final concentration of $3 \mathrm{U} \mathrm{mL}^{-1}$ and the incubation time was increased to $5 \mathrm{~h}$. Algae extracts were diluted serially with final dilution factors ranging from 1 to 729 . Assay calibration was achieved with MC-LR (0.01$5 \mu \mathrm{g}^{-1}$ ), the $100 \%$ control ( $100 \%$ color development) and the $0 \%$ control (assay background) were run on every plate. All extracts, standards and controls were assayed in duplicates on each plate and all analyses were conducted at least three times independently. Measurements were performed in a microplate reader (Infinite M200, Tecan, Crailsheim, Germany).

Adda-ELISA. All extracts were analyzed using a commercially available Adda-ELISA kit (Abraxis LLC, Warminster, PA, USA; cat\# 520011) according to the manufacturer's instructions. This indirect competitive ELISA recognizes specifically the Adda-moiety present in $M C$ and nodularin molecules thus detecting the toxins in a congenerindependent mode (Fischer et al., 2001). All extracts were analyzed in duplicates on each plate and analyses were independently replicated at least three times. Toxin concentrations were calculated based on the MC-LR standard calibration curve $\left(0.15-5 \mu \mathrm{g} \mathrm{L}^{-1}\right)$ and are given as $M C-L R$ equivalents $\left(M C-L R_{e q}\right)$. The limit of detection (LOD) was $0.01 \mu \mathrm{g} \mathrm{L}{ }^{-1}$ according to the manufacturer. Absorbances were read in a microplate reader (Infinite M200, Tecan, Crailsheim, Germany).

Cell culture and cytotoxicity experiments. A549 cells (human alveolar basal epithelial cells) were obtained from the DSMZ, Braunschweig, Germany (\#ACC 107) and were cultured in DMEM/F12, supplemented with $10 \% \mathrm{FBS}, 25 \mathrm{mM}$ Hepes and antibiotics $\left(100,000 \mathrm{UL}^{-1}\right.$ penicillin, $100 \mathrm{mg} \mathrm{L}^{-1}$ streptomycin) under standard conditions $\left(37^{\circ} \mathrm{C}, 5 \% \mathrm{CO}_{2}\right)$. For cytotoxicity experiments all extracts and stock solutions (MC, CYN, solvent) were sterilized by filtration $(0.2 \mu \mathrm{m})$. Cytotoxicity of algae extracts was determined using the MTT reduction assay, as previously described (Dietrich et al., 2001: Mosmann, 1983). A549 cells were seeded into 96-well-plates at a density of $1 \times 10^{4}$ cells $\mathrm{cm}^{-2}$ and the plates were incubated at $37^{\circ} \mathrm{C}$ for $48 \mathrm{~h}$ until confluence was nearly reached. Then medium $(100 \mu \mathrm{L})$ was renewed and $50 \mu \mathrm{L}$ of the algae extracts, the appropriate concentration of test substances or solvent, were added and serially diluted resulting in dilution factors of $3,9,27$ and 81 , corresponding to $41.7,13.9,4.6$ and $1.5 \mathrm{~g} \mathrm{dw}$ algae product $\mathrm{L}^{-1}$. The final concentrations for MC-LR (negative control, due to a lacking MC-LR transporter (Fischer et al., 2010) in the A549 cells) and cylindrospermopsin (positive control) were $0.005-10 \mu \mathrm{M}$ and $0.009-$ $20 \mu \mathrm{M}$, respectively. Final concentrations of $0.06-1.7 \%(\mathrm{v} / \mathrm{v}) \mathrm{MeOH}$ were used as solvent controls. A final concentration of $2.7 \%(\mathrm{v} / \mathrm{v})$ Tween 20 was used as assay control. The treated cells were incubated for $26 \mathrm{~h}$ at $37^{\circ} \mathrm{C}$. After incubating the cells in the presence of MTT $\left(250 \mu \mathrm{gL}^{-1}\right.$ ) at $37^{\circ} \mathrm{C}$ for $1.5 \mathrm{~h}$, the supernatant was discarded and the intracellular formazan was solubilized with $95 \%(\mathrm{v} / \mathrm{v})$ isopropanol/ $5 \%(\mathrm{v} / \mathrm{v})$ formic acid. Absorbances were read at $550 \mathrm{~nm}$ using a microplate reader (Infinite M200, Tecan, Crailsheim, Germany).

Liquid chromatography tandem mass spectrometry (LC-MS/MS) analyses. All toxin analyses were carried out on an Agilent 1100 series HPLC system (Agilent Technologies, Waldbronn, Germany) coupled to a API 4000 triple quadrupole mass spectrometer (Applied Biosystems/MDS Sciex, Framingham, MA) equipped with a turbo-ionspray interface.

MCs and nodularins were analyzed according to Spoof et al. (2003) in SPE-purified algae extracts. The extract was separated using a Purospher STAR RP-18 end-capped column $(30 \times 4 \mathrm{~mm}, 3 \mu \mathrm{m}$ particle size, Merck, Germany) at $30{ }^{\circ} \mathrm{C}$. The mobile phase consisted of $0.5 \%$ formic acid (A) and acetonitrile with $0.5 \%$ formic acid (B) at a flow rate of $0.5 \mathrm{~mL} / \mathrm{min}$ with the following gradient program: 0 min $25 \% \mathrm{~B}, 10 \mathrm{~min} 70 \% \mathrm{~B}$, $11 \mathrm{~min} 70 \% \mathrm{~B}$. The injection volume was $10 \mu \mathrm{L}$. Identification and quantification of the MCs ([Asp $\left.{ }^{3}\right]-M C-R R, M C-R R, M C-Y R,\left[A^{3} p^{3}\right]-M C-L R$, $M C-L R, M C-L W, M C-L F, M C-L A)$ and nodularin was performed in the SRM (Selected Reaction Monitoring) mode. LODs for the congeners were in the range of $0.01-0.20 \mu \mathrm{g} \mathrm{g}^{-1} \mathrm{dw}$.

For the analysis of ATX, CYN and STX as well as other paralytic shellfish poisons (PSPs), algae products were extracted (Dell'Aversano et al., 2004) using a mixture of acetonitril, water and formic acid (75:14.9:0.1). The extracts were separated using a $5 \mu \mathrm{m}, 2 \times 250 \mathrm{~mm}$ TSKgel Amide- $80 \mathrm{col}$ umn (Tosohaas, PA, USA) at $30^{\circ} \mathrm{C}$. The mobile phase consisted of water (A) and acetonitrile-water (95:5) (B), both containing $2.0 \mathrm{mM}$ ammonium formate and $3.6 \mathrm{mM}$ formic acid $(\mathrm{pH} \mathrm{3.5);} \mathrm{the} \mathrm{flow} \mathrm{rate} \mathrm{was}$ $0.2 \mathrm{~mL} \mathrm{~min}^{-1}$. The following gradient program was used for analysis of multiple toxins (CYN, ATX, STX, PSPs): $75 \%$ B for $5 \mathrm{~min}, 75 \%-65 \%$ B over $1 \mathrm{~min}$, hold for $13 \mathrm{~min}, 65-45 \%$ B over $4 \mathrm{~min}$, hold for $10 \mathrm{~min}$. (5). The injection volume was $10 \mu \mathrm{L}$. Identification and quantification of ATX, CYN, STX and other PSPs was performed in SRM mode with the transitions described recently (Dell'Aversano et al., 2004). The LODs were $0.1 \mu \mathrm{g} \mathrm{g}^{-1}$ $\mathrm{dw}$ for ATX and CYN and in the range of 1-10 $\mu \mathrm{g} \mathrm{g}^{-1} \mathrm{dw}$ for the different PSP congeners including STX.

DNA extraction and PCR analysis. DNA extraction was performed according to Saker et al. (2005) with modifications. Briefly, approximately $10 \mathrm{mg}$ of each algae product was used. Products were incubated with $500 \mu \mathrm{L}$ extraction buffer $(100 \mathrm{mM}$ Tris- $\mathrm{HCl}(\mathrm{pH} 7.4), 1 \%(\mathrm{w} / \mathrm{v})$ potassium ethyl xanthogenate, $800 \mathrm{mM}$ ammonium acetate, $20 \mathrm{mM}$ EDTA and $1 \%(w / v)$ SDS) for $2 \mathrm{~h}$ at $65^{\circ} \mathrm{C}$ (vortexed after $1 \mathrm{~h}$ ). Mixtures were then placed on ice for $10 \mathrm{~min}$ and centrifuged at $12,000 \times \mathrm{g}$ for $10 \mathrm{~min}$. The mixture supernatants were extracted twice $(20 \mathrm{~min}$, shaking at RT) with equal volumes of phenol/chloroform/isoamylalcohol (25:24:1) and centrifuged at $12,000 \times \mathrm{g}$ for $10 \mathrm{~min}$. The DNA was precipitated for $15 \mathrm{~min}$ at $4{ }^{\circ} \mathrm{C}$ from the aqueous supernatants using 1 volume of isopropanol and $1 / 10$ volume of $4 \mathrm{M}$ ammonium acetate. Centrifugation at $12,000 \times \mathrm{g}$ for $20 \mathrm{~min}$ pelleted the DNA, which was washed once with $70 \%$ ethanol and air-dried. The final samples were re-suspended in $50 \mu \mathrm{L}$ deionized water. PCR was carried out in $25 \mu \mathrm{L}$ samples containing $1 \times$ Taq master mix (NEB, cat\# M0270S), $2.5 \mathrm{mM}$ $\mathrm{MgCl}_{2}, 50 \mathrm{pmol}$ of each primer (Table 2) and $10 \mathrm{ng}$ DNA.

The $P C \alpha / P C \beta$ primer pair was used to amplify a $650 \mathrm{bp}$ fragment from the phycocyanin operon common to all cyanobacteria (Saker et al., 2007).

Hep primers were used to amplify the mcyE gene, part of the microcystin and nodularin synthetase gene cluster, and thus present in all microcystin and nodularin producing cyanobacteria (AMT, mcyE) (Saker et al., 2005).

Amplification was performed with an initial denaturing step at $92{ }^{\circ} \mathrm{C}$ for $2 \mathrm{~min}$ followed by 35 cycles of $95^{\circ} \mathrm{C}$ for $90 \mathrm{~s}, 52$ or $56^{\circ} \mathrm{C}$ 
Table 2

Oligonucleotide primers used for PCR.

\begin{tabular}{|c|c|c|c|c|c|}
\hline Primer name & Target gene & Sequence & $\begin{array}{l}\text { Size } \\
\text { (bp) }\end{array}$ & Annealing temp. $\left({ }^{\circ} \mathrm{C}\right)$ & Reference \\
\hline PCBF & Phycocyanin & 5'-GGCTGCTTGTTTACGCGACA-3' & 650 & $56^{\circ} \mathrm{C}$ & (Saker et al., 2005, 2007) \\
\hline PCQR & & 5'-CCAGTACCACCAGCAACTAA-3' & & & \\
\hline HepF & AMT, MCYE & 5'- TTTGGGGTTAACTTTTTTGGCCATAGTC-3' & 472 & $52{ }^{\circ} \mathrm{C}$ & (Saker et al., 2005) \\
\hline HepR & & 5'-AATTCTTGAGGCTGTAAATCGGGTTT-3' & & & \\
\hline
\end{tabular}

for $60 \mathrm{~s}$ and $72{ }^{\circ} \mathrm{C}$ for $60 \mathrm{~s}$ and a final extension step at $72{ }^{\circ} \mathrm{C}$ for 7 min. The PCR products were separated on $1.5 \%$ agarose gels with $0.5 \times$ TBE buffer and stained with ethidium bromide. A MultiDoc-It digital imaging system (UVP, LTF Labortechnik, Germany) was used for photographic documentation.

Statistical data analysis. Comparison of the different methods of MC analysis was performed by One-way ANOVA with Tukey's Multiple Comparison Test. Data from cytotoxicity analysis were analyzed by a One-way ANOVA with Dunnett's Multiple Comparison Test. Data from the different dilutions of the algae extracts were analyzed by a Two-way ANOVA with Bonferroni Posttest. Data are presented as means \pm SEM. Significant differences are indicated as follows: $p<0.001$ $\left({ }^{* * *}\right), \mathrm{p}<0.01\left(^{* *}\right), \mathrm{p}<0.05\left(^{*}\right)$ and $\mathrm{p} \geq 0.05$ (not significant). All statistical analyses were performed using GraphPad Prism 5.03 software.

\section{Results}

Toxin analyses

The analysis of microcystins and nodularin by the three different methods CPPIA, Adda-ELISA and LC-MS/MS were in good agreement, i.e. none of the results differed significantly from another achieved via a different method of analysis (Table 3 ). Re-analysis of products with known levels of microcystin (MC-LR equivalents) contamination i.e. Aph04(PC1), Aph05(PC2) and Aph06(NC1), provided for values

Table 3

Comparison of methods for the detection of MCs in algae products. Data (CPPIA and Adda-ELISA) represent means (three independent determinations run in duplicate) \pm standard deviation (SD); LC-MS/MS analyses were run three times for each sample, data is presented as means \pm standard deviation (SD); dw, dry weight; n.d., not detectable due to high color quenching; LOD, limit of detection of the individual method of analysis.

\begin{tabular}{|c|c|c|c|}
\hline \multirow[t]{2}{*}{ Sample \# } & \multicolumn{2}{|c|}{$M C-L R_{e q}\left(\mu g g^{-1} d w\right)$} & \multirow{2}{*}{$\begin{array}{l}\frac{M C\left(\mu g g^{-1} d w\right)}{L C-M S / M S} \\
\text { Means } \pm S D\end{array}$} \\
\hline & $\begin{array}{l}\text { cPPIA } \\
\text { Means } \pm S D\end{array}$ & $\begin{array}{l}\text { Adda-ELISA } \\
\text { Means } \pm \text { SD }\end{array}$ & \\
\hline Aph01a & $0.7 \pm 0.1$ & $1.7 \pm 0.7$ & $1.0 \pm 0.1$ \\
\hline Aph01b & $2.2 \pm 0.9$ & $2.0 \pm 0.7$ & $1.0 \pm 0.1$ \\
\hline Aph02 & $1.8 \pm 0.7$ & $1.1 \pm 0.4$ & $0.9 \pm 0.1$ \\
\hline Aph03 & $0.6 \pm 0.3$ & $0.8 \pm 0.0$ & $0.4 \pm 0.1$ \\
\hline Aph04 (PC1) & $11.0^{\circ}$ & $6.1 \pm 2.6$ & $5.8 \pm 0.9$ \\
\hline Aph05 (PC2) & $1.9 \pm 0.5$ & $1.0 \pm 0.5$ & $1.2 \pm 0.3$ \\
\hline Apho6 (NC1) & $\angle \mathrm{LOD}^{3}$ & $<\mathrm{LOD}^{\mathrm{t}}$ & $<\mathrm{LOD}^{\mathrm{C}}$ \\
\hline Aph07 & $1.0 \pm 0.2$ & $1.3 \pm 0.2$ & $0.5 \pm 0.0$ \\
\hline Aph08 & $0.8 \pm 0.3$ & $0.9 \pm 0.0$ & $0.7 \pm 0.1$ \\
\hline Aph09 & $0.5 \pm 0.2$ & $0.5 \pm 0.2$ & $0.1 \pm 0.0$ \\
\hline Spir01 & $0.1 \pm 0.0$ & $0.1 \pm 0.1$ & $<\mathrm{LOD}^{\mathrm{C}}$ \\
\hline Spir02 & $\angle \mathrm{LOD}^{2}$ & $<\mathrm{LOD}^{\mathrm{b}}$ & $\angle \mathbb{L O D}^{6}$ \\
\hline Spir03 & $\angle L_{O D}$ & $<\mathrm{LOD}^{\mathrm{B}}$ & $\angle \mathrm{LOD}^{\mathrm{C}}$ \\
\hline Spir04 & $\angle L_{O D}$ & $<\mathbf{L O D}^{\mathbf{b}}$ & $<\mathrm{LOD}^{\kappa}$ \\
\hline Spir05 & $<\mathrm{LOD}^{\mathrm{a}}$ & $\angle L_{O D}^{b}$ & $\angle \mathrm{LOD}^{c}$ \\
\hline Chlo01 & $\triangle \mathrm{LOD}^{3}$ & $\angle \mathrm{LOD}^{\mathrm{b}}$ & $\angle L O D^{\varepsilon}$ \\
\hline Chlo02 & n.d. & $<\mathrm{LOD}^{\mathrm{b}}$ & $\angle L_{O D}$ \\
\hline Chlo03 & $\angle \mathrm{L}^{\prime} O D^{\mathrm{a}}$ & $\angle L O D^{\circ}$ & $\angle \mathrm{LOD}^{\mathrm{C}}$ \\
\hline
\end{tabular}

* $n=1$, due to limited extract availability.

a LOD: $0.01 \mu \mathrm{g} M C-\mathrm{LR}_{\mathrm{eq}} \mathrm{L}^{-1}$.

LOD: $0.01 \mu \mathrm{g} M C-\mathrm{LR}_{\mathrm{eq}} \mathrm{L}^{-1}$

c LOD: $0.01-0.20 \mu \mathrm{g} \mathrm{MC} \mathrm{g}^{-1} \mathrm{dw}$ (depending on congener). nearly identical to those determined years ago (Table 4), thus confirming the reliability of the measurements as well as the stability of the compounds in the product samples. The six new Aph. flos-aquae samples all tested positive for microcystin contamination, ranging between 0.4 and $2.2 \mu \mathrm{g}$ MC-LR $\mathrm{Lq}^{-1} \mathrm{dw}$ algae supplement (Table 3). LCMS/MS analysis revealed that the Aph. flos-aquae samples primarily contained MC-LR and most of them also had traces of MC-LA (Table 5 , Fig. 1).

Based on LC-MS/MS analyses, none of the algae dietary products (cyanobacteria and green algae) demonstrated the presence of anatoxin-a, cylindrospermopsin or paralytic shellfish poisons (PSPS) including STX (data not shown).

\section{Determination of cytotoxicity}

To determine potential non-MC specific cytotoxicity preliminary assays with MC-LR established a no-effect-concentration of $\leq 10 \mu \mathrm{M}$ at $26 \mathrm{~h}\left(\mathrm{EC}_{0 ; 26 \mathrm{~h}}\right.$ ) of exposure (data not shown). In contrast, with the positive control for cytotoxicity, CYN, resulted in an $\mathrm{EC}_{50 ; 26 \mathrm{~h}}=$ $20 \mu \mathrm{M}$ (data not shown). As all pure extracts contained high amounts of $\mathrm{MeOH}(20 \%(\mathrm{v} / \mathrm{v}))$, MeOH cytotoxicity was determined at the $\mathrm{MeOH}$ dilutions (dilution factors: $\mathrm{df}=3(20 \% \mathrm{MeOH} / 3), 9(20 \%$ $\mathrm{MeOH} / 9), 27$ (20\% $\mathrm{MeOH} / 27)$ and 81 (20\% $\mathrm{MeOH} / 81)$ ) present in the algae extracts (see Materials and methods). No MeOH related cytotoxicity was observed (Fig. 2). As there was no statistical difference between the various $\mathrm{MeOH}$ dilutions and the untreated control (Fig. 2), all ensuing cytotoxicity results of algae extracts were statistically compared to the untreated control.

In general, all algae extracts showed a high cytotoxicity when tested at low dilutions of the original extract ( 41.7 and $13.9 \mathrm{mg} \mathrm{dw} \mathrm{L} \mathrm{m}^{-1}$ ). whereas low or no cytotoxicity was observed at higher dilutions (4.6 and $1.5 \mathrm{mg} \mathrm{dw} \mathrm{L} \mathrm{L}^{-1}$ ) (Figs. 3-5). Aph. flos-aquae (Fig. 3) and S. platensis (Fig. 4) extracts provided for a very similar toxicity pattern. Generally, C. pyrenoidosa extracts (Fig. 5) appeared to be less cytotoxic.

Table 4

Overview of control samples for the detection of MCs in algae products. Adda-ELSA data are means (from at least three independent determinations run in duplicate) \pm standard deviation (SD); LC-MS/MS analyses were run three times for each sample, data is presented as means \pm standard deviation (SD); $\mathrm{dw}$, dry weight; $\mathrm{NC}$, negative control sample; $P C$, positive control sample; product Aph06 (NC1) and products Aph04 (PC1) and Aph05 (PC2) were bought in 2008 and 2003, respectively; n.d., not determined; LOD, limit of detection of the individual method of analysis.

\begin{tabular}{|c|c|c|c|c|}
\hline \multirow[t]{2}{*}{ Sample \# } & \multirow{2}{*}{$\begin{array}{l}\text { Determination } \\
\text { (Year) }\end{array}$} & \multicolumn{2}{|c|}{$M C-L_{e q}\left(\mu g^{-1} d w\right)$} & \multirow{2}{*}{$\begin{array}{l}M C\left(\mu g^{-1} d w\right) \\
L C-M S / M S \\
M e a n s \pm S D\end{array}$} \\
\hline & & $\begin{array}{l}\text { CPPIA } \\
\text { Means } \pm S D\end{array}$ & $\begin{array}{l}\text { Adda-ELISA } \\
\text { Means } \pm \text { SD }\end{array}$ & \\
\hline Aph06 (NC1) & 2010 & $\angle L^{\prime} D^{a}$ & $\angle \mathrm{LOD}^{\circ}$ & $<\mathrm{LOD}^{6}$ \\
\hline Aphos (NC1) & 2008 & $\angle \mathrm{LOD}^{\mathrm{a}}$ & $\angle L O D$ & $\angle \mathrm{LOD}^{\mathrm{C}}$ \\
\hline Aph04 (PC1) & 2010 & $11.0^{\mathrm{d}}$ & $6.1 \pm 2.6$ & $5.8 \pm 0.9$ \\
\hline Aph04 (PC1) & 2008 & $7.6 \pm 2.3$ & $6.4 \pm 2.4$ & $5.7 \pm 0.1$ \\
\hline Aph04 (PC1) & 2003 & $4.9 \pm 0.3$ & $5.8 \pm 0.5$ & n.d. \\
\hline Aph05 (PC2) & 2010 & $1.9 \pm 0.5$ & $1.0 \pm 0.5$ & $1.2 \pm 0.3$ \\
\hline Aph05 (PC2) & 2008 & $2.1 \pm 0.5$ & $1.7 \pm 0.7$ & $1.1 \pm 0.2$ \\
\hline Aph05 (PC2) & 2003 & $1.5 \pm 0.3$ & $1.3 \pm 0.2$ & n.d. \\
\hline
\end{tabular}

a LOD: $0.01 \mu \mathrm{g} M C-L R_{\text {eq }} L^{-1}$.

b LOD; $0.01 \mu \mathrm{g}$ MC-LR $\mathrm{L}^{-1}$

c LOD: $0.01-0.20 \mu \mathrm{g} \mathrm{MC} \mathrm{g}^{-1} \mathrm{dw}$ (MC congener dependent).

d $n=1$, due to limited extract availability. 
Table 5

LC-MS/MS detection of MC congeners in algae products. LC-MS/MS analyses were run three times for each sample; data are means \pm standard deviation (SD); dw, dry weight; limit of detection of the LC-MS/MS for the individual MC congeners (LOD):

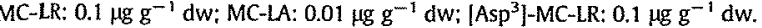

\begin{tabular}{lllll}
\hline Sample \# & \multicolumn{3}{l}{ MCs $\left(\mu \mathrm{g} \mathrm{g}^{-1} \mathrm{dw}\right)$} & \\
\cline { 2 - 5 } & $\begin{array}{l}\text { MC-LR } \\
\text { Means } \pm \text { SD }\end{array}$ & $\begin{array}{l}\text { MC-LA } \\
\text { Means } \pm \text { SD }\end{array}$ & $\begin{array}{l}\text { [Asp]-MC-LR } \\
\text { Means } \pm S D\end{array}$ & $\begin{array}{l}\text { MC sum } \\
\text { Means } \pm S D\end{array}$ \\
\hline Aph01a & $0.8 \pm 0.1$ & $0.2 \pm 0.0$ & $<$ LOD & $1.0 \pm 0.1$ \\
Aph01b & $0.7 \pm 0.1$ & $0.2 \pm 0.0$ & $<$ LOD & $1.0 \pm 0.1$ \\
Aph02 & $0.7 \pm 0.0$ & $0.2 \pm 0.0$ & $<$ LOD & $0.9 \pm 0.1$ \\
Aph03 & $0.3 \pm 0.1$ & $0.1 \pm 0.0$ & $<$ LOD & $0.4 \pm 0.1$ \\
Aph04 (PC1) & $5.4 \pm 0.8$ & $0.3 \pm 0.1$ & $0.1 \pm 0.1$ & $5.8 \pm 0.9$ \\
Aph05 (PC2) & $1.2 \pm 0.2$ & $0.1 \pm 0.0$ & $<$ LOD & $1.2 \pm 0.3$ \\
Aph06 (NC1) & $<$ LOD & $<L O D$ & $<$ LOD & $<L O D$ \\
Aph07 & $0.3 \pm 0.1$ & $0.1 \pm 0.0$ & $<$ LOD & $0.5 \pm 0.0$ \\
Aph08 & $0.6 \pm 0.1$ & $0.1 \pm 0.0$ & $<$ LOD & $0.7 \pm 0.1$ \\
Aph09 & $0.1 \pm 0.0$ & $<$ LOD & $<$ LOD & $0.1 \pm 0.0$ \\
\hline
\end{tabular}

However, cytotoxicity seemed to be strongly lot dependent for all algae product extracts tested.

The cytotoxicity detected was also confirmed microscopically, where slightly affected $A 549$ cells presented with blebbing, vacuolization, single cell necrosis (Fig. 6B) and severely affected cells presented with overt and widespread necrosis along with loss of cellular integrity (Fig. 6C).

\section{Determination of cyanobacterial and MC-specific genes}

PCR analysis (Fig. 7) corroborated the results obtained for MC analyses. The mcyE gene was not detectable in two cases only (Aph03, Aph09), despite that the toxin analysis was positive for MC.

For PCR control, the phycocyanin gene (a pigment from the light-harvesting phycobili protein family) was used as a marker for cyanobacteria. As expected, Aph. flos-aquae products (with the exception of sample Aph06) presented strong bands and C. pyrenoidosa products were negative. Chlorella product Chlo01 showed a strong positive band, which was expected due to the mixed nature of the product (91\% C. pyrenoidosa and 9\% Aph. flos-aquae according to the supplier). Unexpectedly S. platensis products were negative. However, the latter
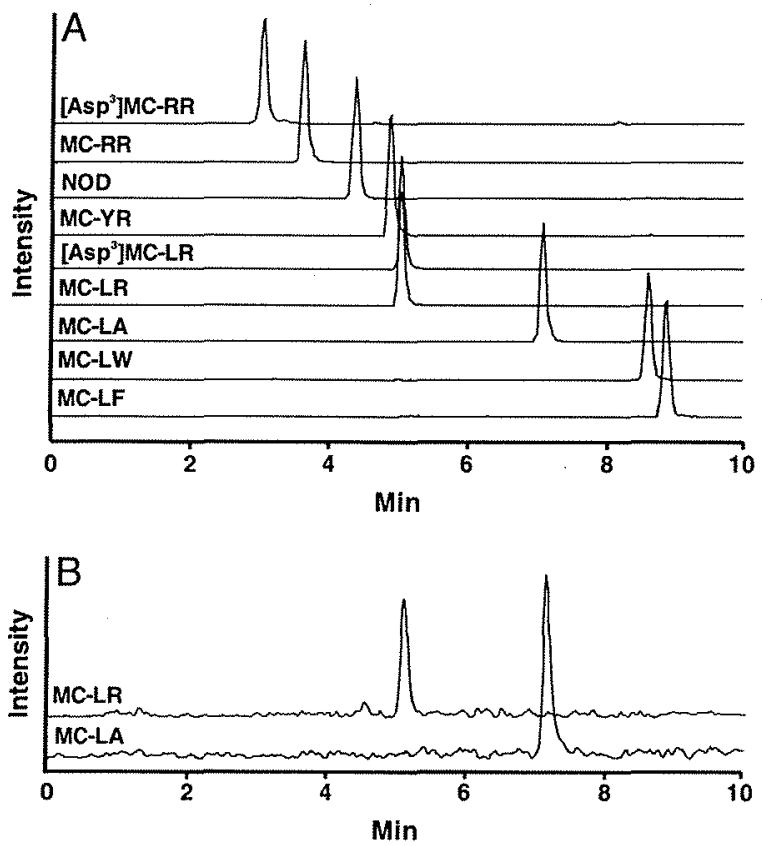

Fig. 1. Reconstructed LC-MS/MS chromatograms. A, Standands ([Asp ${ }^{3}$ ]-MC-RR, MC-RR, NOD (nodularin), MC-YR, [Asp $\left.\left.{ }^{3}\right]-M C-L R, M C-L R, M C-L A, M C-L W, M C-L F\right) ; B$, sample Aph02.

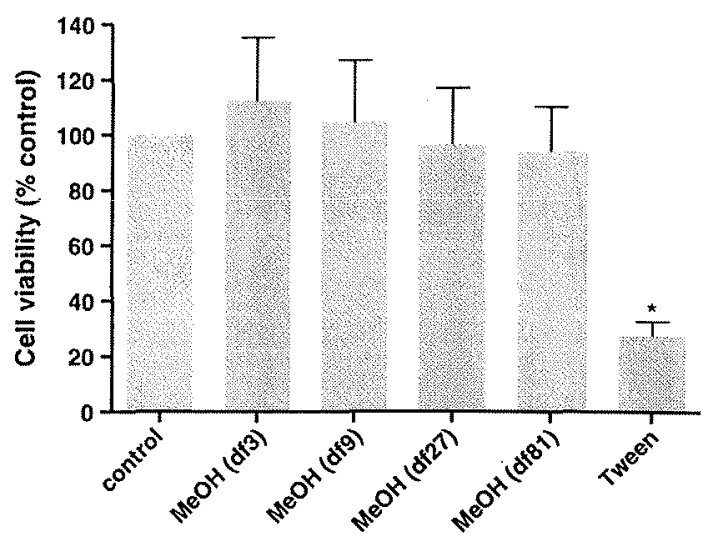

Fig. 2. Cytotoxicity of MeOH and controls in A549 cell MTT assay after $26 \mathrm{~h}$ of exposure; dilution factors (df) were applied on $20 \% \mathrm{MeOH}$; data represent means \pm SEM (from ten independent determinations $(n=10)$ run in technical duplicates); ANOVA with Dunnett's multiple comparison test with $\mathrm{p}<0,05\left(^{*}\right)$.

is not surprising as the primers employed (Table 2) were originally designed to detect the Aph. flos-aquae phycocyanine gene (Saker et al., $2005,2007)$ and therefore unlikely to be suitable for detection of the phycocyanin gene in S. platensis products.

\section{Discussion}

The analysis for the presence of cyanobacterial toxins (MCs, nodularins, saxitoxins, anatoxin-a and cylindrospermopsin) encompassed only algae dietary supplements marketed in Germany and thus only the three main types of algae generally used for the production of dietary supplements, i.e. Aph. flos-aquae, Spirulina and Chlorella, thereby restricting the interpretation of the findings to these type of products. The latter analyses demonstrated the absence of nodularins, saxitoxins, anatoxin-a and cylindrospermopsin in these products, whereas all Aph. flos-aquae based products and mixtures thereof were positive for MC contamination. The methods employed for toxin analyses encompassed the most sensitive detection methods currently available, providing for limits of detection (LOD) in the range of $0.1 \mu \mathrm{g} \mathrm{g}^{-1} \mathrm{dw}$ for ATX and CYN, $1-10 \mu \mathrm{g} \mathrm{g}^{-1} \mathrm{dw}$ for the different PSP congeners incl. STX, and 0.01-0.2 $\mu \mathrm{g} \mathrm{g}^{-1} \mathrm{dw}$ for MCs (Tables 3-5). The comparison of methods employed for MC detection (CPPIA, Adda-ELISA and LC-MS/MS) demonstrated that none of the results obtained with the individual methods differed significantly from another (Table 3 ), thereby confirming that a reliable determination of MC contamination of algae dietary supplements can be obtained with any of the methods used and presented in this paper. Additional corroboration of MC contamination was sought by confirming the presence of an MC-producing cyanobacteria. The latter was achieved by the detection of the mcyE gene, part of the microcystin and nodularin synthetase gene cluster, and thus present in all microcystin and nodularin producing cyanobacteria (AMT, mcyE) (Saker et al., 2005). With the exception in two products (Aph03 and Aph09), $m c y E$ PCR product was demonstrated in all algae dietary supplements containing either $100 \%$ of Aph. flos-aquae (Fig. 7) or a mixture containing Aph. flos-aquae. Dietary supplements Aph03 and Aph09 did not allow for a detectable PCR product, despite that toxin analysis showed an MC contamination of the respective product extracts (Tables 3, 5 and 6). The latter may be due to an expression below the detection limit of the PCR method employed. Indeed, these products also had the lowest level of MC contamination when compared to the other products. Overall, the above data strongly suggest that MC-producing cyanobacterial species are present in the algae dietary supplement products analyzed and thus this explains the presence of MCs in the product extracts. 

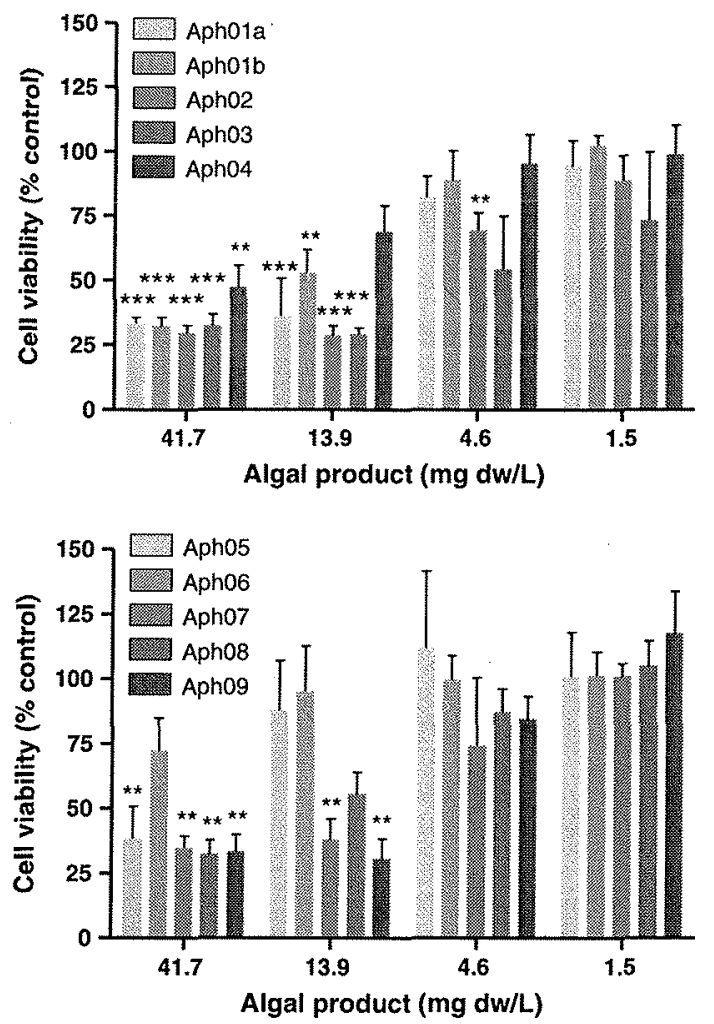

Fig. 3. Cytotoxicity of Aph.flos-aquae extracts in A549 cells. MTT assay after $26 \mathrm{~h}$ of exposure; data represent means \pm SEM (from four independent determinations $(n=4)$ run in technical duplicates); Two-way ANOVA with Bonferroni posttest with $\mathrm{p}<0.001\left(^{* * *}\right)$, $p<0.01\left(^{* *}\right)$.

The degree of MC contaminations found in the algae dietary supplements correspond well with those reported earlier for European (Hoeger and Dietrich, 2004; Vinogradova et al., 2011; Vichi et al., 2012; Fischer et al., unpublished results), US and Canadian (Gilroy et al., 2000; Saker et al., 2005, 2007) and Australian (Saker et al., 2007) markets. Detailed MC analysis demonstrated that MC contamination consisted primarily of MC-LR and traces of MC-LA, again similar to the findings reported by earlier European analyses (Fischer et al., unpublished results; Hoeger and Dietrich, 2004; Vichi et al., 2012; Vinogradova et al., 2011) and thus confirming that these products appear to stem from the same production area or even primary producer.

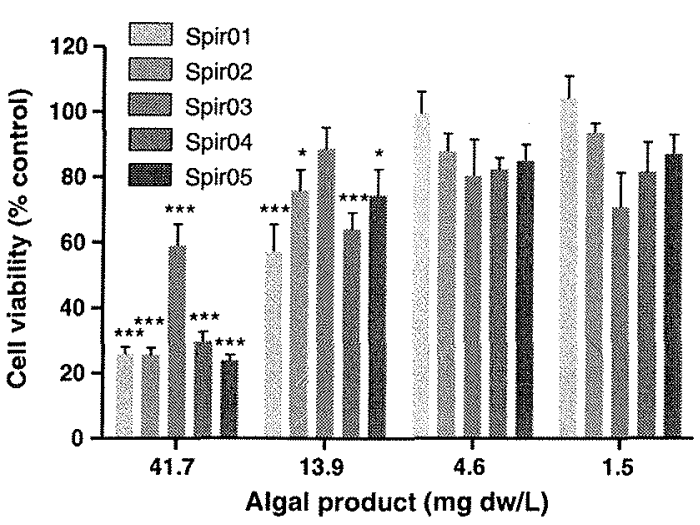

Fig. 4. Cytotoxicity of S. platensis extracts in A549 cells. MTT assay after 26 h of exposure data represent means \pm SEM (from four independent determinations $(n=4)$ run in technical duplicates); Two-way ANOVA with Bonferroni posttest with $\mathrm{p}<0.001\left({ }^{* * *}\right), \mathrm{p}<0.05\left(^{*}\right)$
Since their release on the market and subsequent to some public inquiries with regard to adverse health effects of these products, the producers of the Aph. flos-aquae products have been repeatedly claiming that their products are safe. The latter statement was later amended with the more cautionary statement that the products are certified to have MC contamination below the regulatory limit of $1 \mu \mathrm{g} \mathrm{MC}_{\mathrm{eq}} \mathrm{g}^{-1} \mathrm{dw}$ for $\mathrm{BGA}$-containing products originally established by the Oregon Department of Health (ODH) and the Oregon Department of Agriculture (ODA) (Gilroy et al., 2000). A provisional tolerable daily intake (pTDI) of $0.04 \mu \mathrm{g} M C-\mathrm{LR}_{\mathrm{eq}} / \mathrm{kg}$ bw and day was established (Gilroy et al., 2000) and was used by the WHO for calculation of guid-

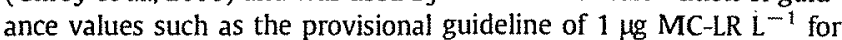
drinking water (WHO, 1998, 1999). Similarly, this pTDI is currently used as regulatory guidance for maximal contamination and/or daily exposure dietary levels in many other countries (Mulvenna et al., 2012). However, while regulation in Oregon (USA) is at the level of the product ( $1 \mu \mathrm{g} \mathrm{MC}_{\mathrm{eq}} \mathrm{g}^{-1} \mathrm{dw}$ for BGA-containing products), other countries e.g. Switzerland, regulate the products based on consumption and allow a maximum daily exposure for adults of $2 \mu \mathrm{g} M C-L R_{\text {eq }}$ and correspondingly lower amounts in children and infants (FOPH). Based on the pTDI, infants $(5 \mathrm{~kg})$, children $(20 \mathrm{~kg})$ and adults $(60 \mathrm{~kg})$ could tolerate a maximum exposure of $0.2,0.8$ and $2.4 \mu \mathrm{g}$ MCs per day, respectively (Fromme et al., 2000; Dietrich and Hoeger, 2005; Dietrich et al., 2008). However, as demonstrated in this study (Table 6 and Fig. 8) the maximum daily exposure of adults, children and infants largely depends on the level of MC contamination in and the daily consumption recommended for the respective algae dietary supplement product. Moreover, Fig. 8 also clearly demonstrates that nearly all algae dietary supplements containing Aph. flos-aquae exceed the daily tolerable exposure of MCs for infants, and all pure Aph. flos-aquae based dietary supplements exceed the daily tolerable exposure of MCs for children.

MCs are known for their acute hepatotoxic effects predominantly via inhibition of protein phosphatases (Mackintosh et al., 1995). Chronic effects include tumor-promotion (Humpage and Falconer, 1999; Nishiwaki-Matsushima et al., 1992), which has led to the classification of MC-LR as a potential human carcinogen (2B) by the International Agency for Research on Cancer (IARC) of the WHO (Grosse et al., 2006). Neurotoxic effects and an involvement of MC exposure in the onset and exacerbation of human neurodegenerative diseases are currently under debate and cannot be ruled out (Feurstein, 2011; Feurstein et al., 2011; Li et al., 2012).

It is thus crucial to emphasize that current pTDI calculations do not include the potential neurotoxic effects. Moreover, the whole $\mathrm{MC}$ risk assessment is based on the toxicological dataset for one MC congener, namely MC-LR, only (Gilroy et al., 2000). However, there are $\geq 90 \mathrm{MC}$

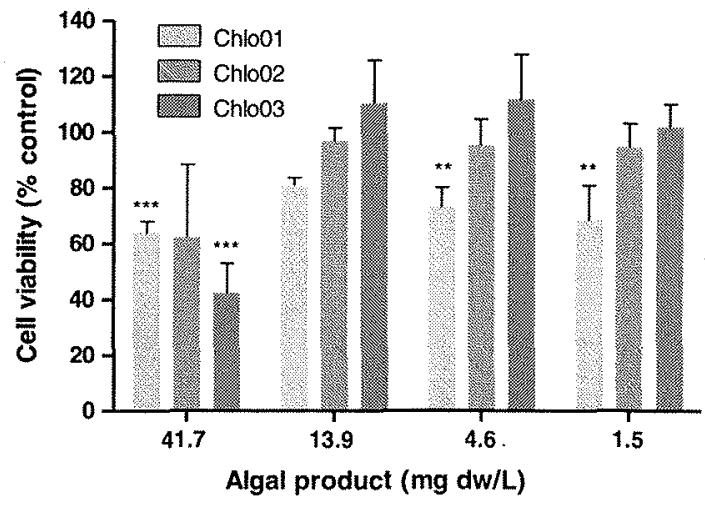

Fig. 5. Cytotoxicity of C. pyrenoidosa extracts in A549 cells. MTT assay after 26 h of exposure; data represent means $t$ SEM ( from four independent determinations $(n=4)$ run in technical duplicates); Two-way ANOVA with Bonferroni posttest with $\mathrm{p}<0.001\left(^{* * *}\right.$ $\mathrm{p}<0.01\left(^{* *}\right)$. 

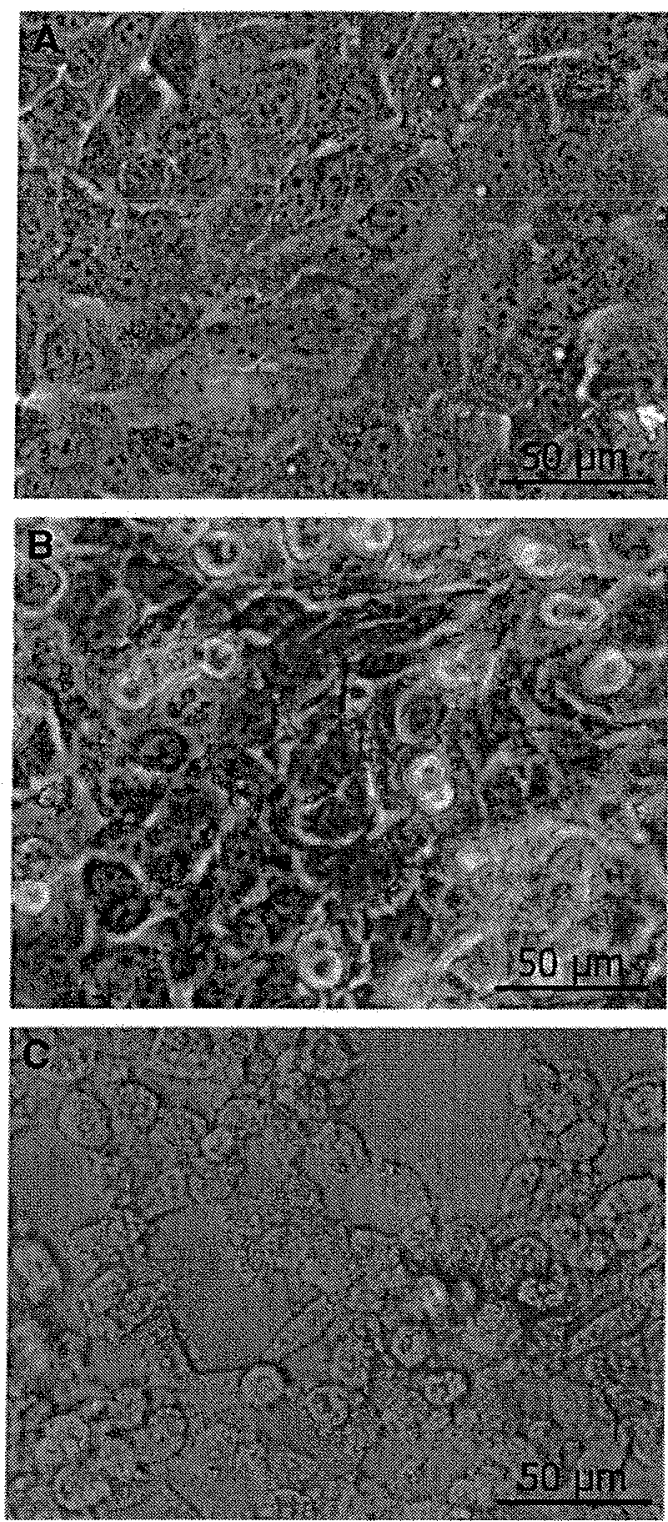

Fig. 6. Representative pictures of A549 cells. A. Untreated cells; B, Chlo01 extract exposed cells; C, Aph04 extract exposed cells.

congeners, some of which may have an overall greater toxicity than MC-LR (Dietrich et al., 2008). Indeed, congeners MC-LF and -LW although having similar PP inhibition capacities as MC-LR were demonstrated to be taken up via organic anion transporting polypeptides (Oatps) much faster and thus having an overall higher cytotoxicity in human transfected HEK 293 (Fischer et al., 2010) and in murine neuronal cells (Feurstein et al., 2011). The latter emphasizes that the current risk assessment of MCs in food, dietary supplements and water is far from being safely established. Consequently and in order to prevent later onset of tumors and/or neurodegenerative effects in humans, exposure to MCs should be minimized at all cost (drinking water and seafood, Mulvenna et al., 2012) and where possible prevented entirely. Whereas exposure to MCs via drinking water and seafood can be controlled and individual consumption estimated the latter is not the case for Aph. flos-aquae based dietary supplement products. Thus, only prohibition of marketing and sale of Aph. flos-aquae based dietary supplement products would prevent acute and chronic excessive exposure to MCs.

In addition to the quantitative analysis of certain toxins, other potential adversely active ingredients of the supplements were investigated using a cell culture-based approach. For this, the human alveolar epithelial cell line A549 was chosen as it could be assumed that these cells do not possess cellular transporter systems enabling MC uptake (Oatps, Fischer et al., 2005, 2010). Testing with MC-LR up to $10 \mu \mathrm{M}$ for $26 \mathrm{~h}$ of exposure resulted in no observable cytotoxicity thus confirming the latter assumption of absence of OATPs. Indeed, cells expressing the respective OAPTs would present with $I C_{50}$ values for MC-LR in the $\mathrm{nM}$ range (Fischer et al., 2010). Thus all algae dietary supplement product extract mediated cytotoxicity in the A549 cell system chosen (Figs. 2-6) can be considered to stem from extract components other than the solvent (MeOH) or toxins analyzed in the extracts (MCs, nodularins, saxitoxins, anatoxin-a and cylindrospermopsin). Indeed, dietary supplement product extract cytotoxicity was reported earlier (Bechelli et al., 2011: Pane et al., 2008; Smital et al., 2011) and thus corroborate the present findings. Similar to the cell blebbing, single and multiple cell necrosis observed here, Bechelli et al. (2011) reported Spirulina and Aph. flos-aquae product extract mediated apoptosis and changes in the cell cycle, but no formation of ROS. To date, the cytotoxic components in the dietary supplement extracts responsible for the effects observed have not been identified, albeit it is known that algae readily absorb heavy metals e.g. lead or mercury and can result in contamination levels in the harvested products in the range of $\mu \mathrm{g} \mathrm{g}^{-1}$ (Fugh-Berman, 2003). However, the overt cytotoxicity observed in the cell assays may provide an explanation for the acute adverse health effects such as nausea, vomiting, diarrhea, constipation and upset stomach reported by consumers of these products (Braun and Cohen, 2010). Allergic reactions including asthmatic wheezing, hay fever or conjunctivitis, and skin irritations have also been reported as have drug interactions with antihistamines, blood-thinners and diabetes medications. Several case reports exist that appear to corroborate the health risks associated with consumption of algae dietary supplements. Acute rhabdomyolysis was reported in a 28-year old man following ingestion of Spirulina supplements for one month (Mazokopakis et al., 2008), generalized seizures associated with hypercalcemia of a day-old baby was found to be related to the mother's long-term consumption of Spinulina supplements (Moulis et al., 2012) and anaphylaxis was reported in a 14-year-old adolescent who had previously experienced urticaria, labial oedema and asthma $6 \mathrm{~h}$ after consumption of five Spirulina tablets (Petrus et al., 2010).

Beyond the fact that open water surface cultivation or harvesting of algae products for production of dietary supplements always encompasses the chance that the final products may contain human pathogens, e.g. Cryptosporidia, Campylobacter and $E H E C$, this analysis

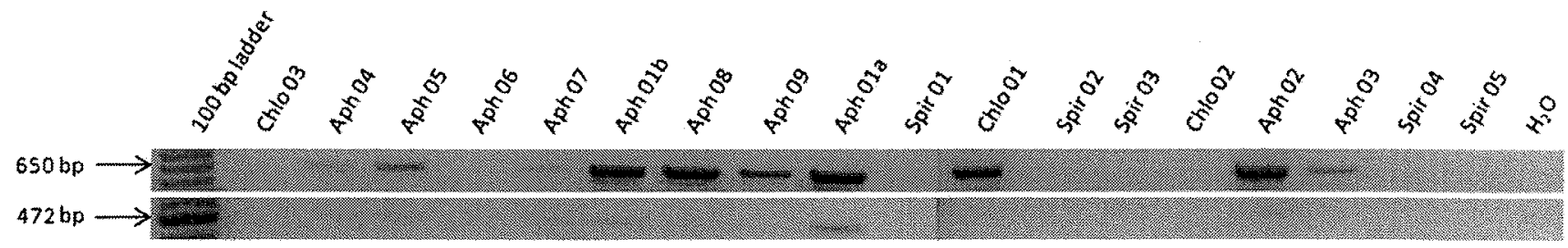


Table 6

Calculation of daily human MC exposure. Based on the daily consumptions of algae dietary supplements as recommended by the producers/distributers and the MC contamination detected, the minimum and maximum daily MC exposure per person was calculated.

\begin{tabular}{|c|c|c|c|c|c|}
\hline Sample \# & Presented form & Recommended daily consumption & Assumed daily consumption $(g)$ & $\begin{array}{l}\text { MC detected } \\
(\text { Min-Max) } \\
\left(\mu g g^{-1} \mathrm{dw}\right)\end{array}$ & $\begin{array}{l}\text { Daily MC exposure based on dietary consumption } \\
\text { (Min-Max) } \\
\text { Total MC (Hg) }\end{array}$ \\
\hline Aphola & $400 \mathrm{mg} /$ pellet & $4-6$ pellets & $2.4 \mathrm{~g}$ & $0.7-1.7$ & $1.7-4.1$ \\
\hline Apho1b & $400 \mathrm{mg} /$ pellet & 4-6 pellets & $2.4 \mathrm{~g}$ & $1.0-2.2$ & $2.4-5.3$ \\
\hline Aph02 & $500 \mathrm{mg} /$ tablet & 3 tablets & $1.5 \mathrm{~g}$ & $0.9-1.8$ & $1.4-2.7$ \\
\hline Aph03 & $495 \mathrm{mg} / \mathrm{capsule}$ & $2-3$ capsules & $1.5 \mathrm{~g}$ & $0.4-0.8$ & $0.6-1.2$ \\
\hline Aph04 (PC01) & $250 \mathrm{mg} /$ capsule & up to 4 capsules & $1 \mathrm{~g}$ & $5.8-11.0$ & $5.8-11.0$ \\
\hline Aph05 (PC02) & Powder & $1.5-2.5 \mathrm{~g}$ & $2.5 \mathrm{~g}$ & $1.0-1.9$ & $2.5-4.8$ \\
\hline Aph07 & $250 \mathrm{mg} / \mathrm{tablet}$ & $4-6$ tablets & $1.5 \mathrm{~g}$ & $0.5-1.3$ & $0.8 \sim 2.0$ \\
\hline Aph08 & Pellets & 6 pellets $(-1.5 \mathrm{~g})$ & $1.5 \mathrm{~g}$ & $0.7-0.9$ & $1.1-1.4$ \\
\hline Aph09 & $400 \mathrm{mg} / \mathrm{tablet}$ & $3 \times 3-5$ tablets & $6 \mathrm{~g}$ & $0.1-0.5$ & $0.1-3.0$ \\
\hline Spiro1 & $400 \mathrm{mg} / \mathrm{tablet}$ & 6-12 tablets & $4.8 \mathrm{~g}$ & 0.1 & 0.5 \\
\hline
\end{tabular}

clearly demonstrated that a high proportion of the algae dietary supplements available on the German market is contaminated with considerable, but varying amounts of MCs. Moreover, cytotoxicity analyses suggest that additional components are present that have the potential to induce fulminant adverse effects in consumers. Thus only prohibition of these products for sale on the national and international markets in combination with strict monitoring by health authorities will protect consumers from serious acute as well as chronic adverse health effects.

\section{Abbreviations}

$\mathrm{MeOH}$ methanol

SPE solid phase extraction

PP protein phosphatase

MC microcystin

NOD nodularin

ATX anatoxin-a

CYN Cylindrospermopsin

PSPS paralytic shellish poisons

CPPIA colorimetric protein phosphatase inhibition assay

LOD limit of detection

FBS fetal bovine serum

LC-MS/MS liquid chromatography tandem mass spectrometry

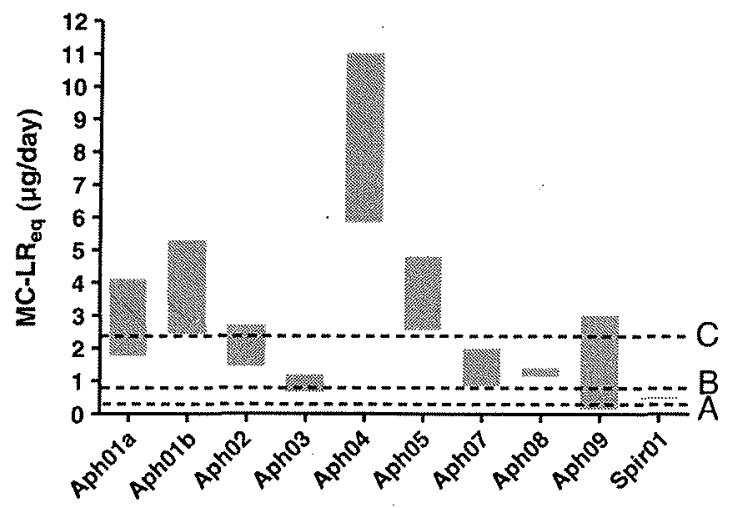

Fig. 8. Range between minimum and maximum MC exposures from algae dietary product (values dependent on method used for analysis) calculated as MC-LR $R_{\mathrm{eq}}(\mu \mathrm{gg} / \mathrm{day}$ ) in comparison to the maximum tolerable daily exposures calculated for infants, children and adults. Calculations were based on the provisional tolerable daily intake (pTDI) of $0.04 \mu \mathrm{gC} / \mathrm{kg}$ bw and day that had been used by the ODH (Gilroy et al., 2000) and WHO (WHO, 1998, 1999) for calculation of guidance values such as the provisional guideline of $1 \mathrm{Hg} \mathrm{MC-LR} \mathrm{L}{ }^{-1}$ for drinking water. Correspondingly, A: infants (5 $\left.\mathrm{kg}\right), \mathrm{B}$ : children $(20 \mathrm{~kg})$ and $C:$ adults $(60 \mathrm{~kg}$ ) could tolerate daily ingestions of $A: 0.2, B: 0.8$ and $C: 2.4 \mu \mathrm{g}$ MC-L.R eq, respectively (Dietrich and Hoeger, 2005; Dietrich et al., 2008; Fromme et al., 2000).
RT room temperature

$B G A(S)$ blue-green algae (supplement)

MC-LR eq MC-LR equivalents

MTT 3-(4,5-dimethylthiazol-2-yl)-2,5-diphenyltetrazolium bromide

\section{Conflict of interest statement}

Daniel R. Dietrich is the patent owner of the Adda-ELISA used for MC analysis.

\section{Acknowledgments}

Stiftung Warentest, Berlin, Germany, financially supported part of the study and provided the testing samples, which were randomly collected from the market. The sponsor was not involved in the study design, data analysis or interpretation.

The authors would like to thank C. Ossenberg for her technical assistance.

\section{References}

Ballot, A., Fastner, J., Lentz, M., Wiedner, C., 2010a. First report of anatoxin-a-producing cyanobacterium Aphanizomenon issatschenkoi in northeastern Germany. Toxicon 56, 964-971.

Ballot, A., Fastner, J., Wiedner, C., 2010b. Paralytic shellfish poisoning toxin-producing cyanobacterium Aphanizomenon gracile in northeast Germany. Appl. Environ. Microbiol. $76,1173-1180$

Bechelli; J., Coppage, M. Rosell, K., Liesveld, J., 2011. Cytotoxicity of algae extracts on normal and malignant cells. Leuk. Res. Treat. Article ID 373519.

Belay, A., Ota, Y., Miyakawa, K. Shimamatsu, H., 1993. Current knowledge on potential health benefits of Spirulina. J. Appl. Phycol. 5, 235-241.

Belay, A., Ota, Y., Miyakawa, K., Shimamatsu, H., 1994. Production of high quality Spinulina at Earthrise Farms. Second Asia-Pacific Conference on Algal Biotechology, Malaysia.

Braun, L, Cohen. M., 2010. Herbs \& Natural Supplements: An Evidence-based Guide. Churchill Livingstone.

Carmichael, W., Drapeau, C, Anderson, D., 2000. Harvesting of Aphanizomenon flos-aquae Ralfs ex Born \& Flah var flos-aquae (Cyanobacteria) from Klamath Lake for human dietary use. J. Appl. Phycol. 12, 585-595.

Clark, R.F., Williams, S.R., Nordt, S.P., Manoguerra, A.S., 1999. A review of selected sedfood poisonings. Undersea Hyperb. Med. 26, 175-184.

Cox, P., Banack, S., Murch, S., Rasmussen, U., Tien, G., Bidigare, R., Metcalf, J., Morrison, L., Codd, G., Bergman, B., 2005. Diverse taxa of cyanobacteria produce beta-Nmethylamino-i-alanine, a neurotoxic amino acid. Proc. Natl. Acad. Sci. U. S. A. $102,5074-5078$.

Dell'Aversano, C, Eaglesham, G.K, Quilliam, M.A., 2004. Analysis of cyanobacterial toxins by hydrophilic interaction liquid chromatography-mass spectrometry. J. Chromatogr. A 1028, 155-164.

Dietrich, D., Hoeger, S., 2005, Guidance values for microcystins in water and cyanobacterial supplement products (blue-green algal supplements): a reasonable or misguided approach? Toxicol. Appl. Pharmacol. 203, 273-289.

Dietrich, D., O'Brien, E., Stack, M., Heussner, A., 2001. Species- and sex-specific renal cytotoxicity of ochratoxin A and B in vitro. Exp. Toxicol. Pathol, 53, 215-225.

Dietrich, D., Fischer, A., Michel, C., Hoeger, S., 2008. Chapter 39: Toxin mixture in cyanobacterial blooms - a critical comparison of reality with current procedures employed in human health risk assessment. In: Hudnell, K. (Ed.), Cyanobacterial Harmful Algal Blooms: State of the Science and Research Needs. Springer. 
Fastner, J., Rücker, J., Stüken, A., Preussel, K., Nixdorf, B., Chorus, l., Köhler, A., Wiedner, C. 2007. Occurrence of the cyanobacterial toxin cylindrospermopsin in northeast Germany. Environ. Toxicol. 22, 26-32.

Ferreira, F., Franco Soler, J., Fidalgo, M., Fernández-Vila, P, 2001. PSP toxíns from Aphanizomenon flos-aquae (cyanobacteria) collected in the Crestuma-Lever reservoir (Douro river, northern Portugal). Toxicon 39, 757-761.

Feurstein. D., 2011. Individual and Combined Neurotoxic Effects of Cyanobacterial Toxins: Neurotoxic Potential of Microcystins. Suedwestdeutscher Verlag fuer Hochschulschriften.

Feurstein, D., Stemmer, K., Kleinteich, J., Speicher, T., Dietrich, D., 2011. Microcystin congener- and concentration-dependent induction of murine neuron apoptosis and neurite degeneration. Toxicol. Sci. 124,424-431.

Fischer, W., Garthwaite, I., Miles, C., Ross, K., Aggen, J., Chamberlin, A., Towers, N., Dietrich, D., 2001. Congener-independent immunoassay for microcystins and nodularins. Environ. Sci. Technol. 35 (24), 4849-4856

Fischer, W.J., Altheimer, S., Cattori, V., Meier, P.J., Dietrich, D.R., Hagenbuch, B., 2005. Organic anion transporting polypeptides expressed in liver and brain mediate uptake of microcystin. Toxicol. Appl. Pharmacol. 203, 257-263.

Fischer, A., Hoeger, S.J., Stemmer, K. Feurstein, D.J., Knobeloch. D., Nussler, D., Dietrich, D.R., 2010. The role of organic anion transporting polypeptides (OATPS/SLCOs) in the toxicity of different microcystin congeners in vitro: a comparison of primary human hepatocytes and OATP-transfected HEK293 cells. Toxicol. Appl. Pharmacol. 245.

Fischer, A., Hoeger, S.J., Fastner, J., Robertson, A, Dietrich, D.R, unpublished results. Detection of microcystins and $\beta-\mathrm{N}$-methylamino-L-alanine in blue-green algae supplements.

FOPH, a. Swiss Federal Office of Public Health Afa-Algen-Produkte [online]. available at: http:/www.bag.admin.ch/themen/lebensmittel/04861/04961/index.html?lang=de accessed on 06.08 .2012 .

Fromme, H., Köhler, A., Krause, R., Fihrling, D., 2000. Occurrence of cyanobacterial toxins-microcystins and anatoxin-a-in Berlin water bodies with implications to human health and regulations. Environ. Toxicol. 15, 120-130.

Fugh-Berman, A., 2003. The 5-Minute Herb and Dietary Supplement Consult. Lippincott Williams \& Wilkins.

Gilroy, D.J. Kauffman, K.W., Hall, R.A., Huang, X., Chu, F.S., 2000. Assessing potential health risks from microcystin toxins in blue-green algae dietary supplements. Environ. Health Perspect. 108, 435-439.

Grosse, Y., Baan, R., Straif, K., Secretan, B., El Ghissassi, F., Cogliano, V., 2006. Carcinogenicity of nitrate, nitrite, and cyanobacterial peptide toxins. Lancet Oncol. 7, 628-629.

Heresztyn, T, Nicholson, B.C., 2001. Determination of cyanobacterial hepatotoxins directly in water using the protein phosphatase inhibition assay. Water Res. 35, 3049-3056.

Hoeger, S., Dietrich, D., 2004. Possible health risks arising from consumption of blue-green algae food supplements. Sixth International Conference on Toxic Cyanobacteria, Bergen, Norway.

Hoeger, S.]., Haarscheidt, D., Dietrich, D.R., 2003. Toxische Sekundärmetabolite in cyanobakteriellen Nahrungsergänzungsmitteln. Federal Office of Public Health FOPH, Switzerland.

Humpage, A., Falconer, I. 1999. Microcystin-LR and liver tumor promotion: effects on cytokinesis, ploidy, and apoptosis in cultured hepatocytes. Environ. Toxicol. 14, 61-75.

Jiang, Y., Xie, P., Chen, J., Liang, G., 2008. Detection of the hepatotoxic microcystins in 36 kinds of cyanobacteria Spirulina food products in China. Food Addit. Contam. Part A Chem. Anal. Control Expo. Risk Assess. 25 (7), 885-894.

Landsberg, J.H., 2002. The effects of harmful algal blooms on aquatic organisms. Rev. Fish. Sci. 10, 113-390

Li, G., Cai, F., Yan, W., Li, C., Wang, J., 2012. A proteomic analysis of MC-LR-induced neurotoxicity: implications for Alzheimer's disease. Toxicol. Sci. 127, 485 495.

MacKintosh, R.W., Dalby, K.N., Campbeli, D.G., Cohen, P.T., Cohen, P., MacKintosh, C., 1995. The cyanobacterial toxin microcystin binds covalently to cysteine-273 on protein phosphatase 1. FEBS Lett. 371, 236-240.

Mahmood, N., Carmichael, W., 1986. Paralytic shellish poisons produced by the freshwater cyanobacterium Aphanizomenon flos-aquae NH-5. Toxicon 24, 175-186.

Marles, R., Barrett, M., Barnes, J., Chavez, M., Gardiner. P., Ko, R., Mahady, G., Low Dog, T., Sarma, N., Giancaspro, G., Sharaf, M. Griffiths, J., 2011. United States pharmacopeia safety evaluation of Spirulina. Crit. Rev. Food Sci. Nutr. 51, 593-604.

Mazokopakis, E., Karefilakis, C., Tsartsalis, A., Milkas, A., Ganotakis, E., 2008. Acute rhabdomyolysis caused by Spirulina (Arthrospira platensis). Phytomedicine 15, $525-527$.
Mosmann, T., 1983, Rapid colorimetric assay for cellular growth and survival: application to proliferation and cytotoxicity assays. J. Immunol. Methods $65,55-63$.

Moulis, G., Batz, A., Durrieu, G., Viard, C., Decramer, S., Montastruc, J., 2012. Severe neonatal hypercalcemia related to maternal exposure to nutritional supplement containing Spinulina. Eur. J. Clin. Pharmacol, 68, 221-222.

Mulvenna, V., Dale, K., Priestly, B., Mueller, U., Humpage, A, Shaw, G., Allinson, G. Falconer, l., 2012. Health risk assessment for cyanobacterial toxins in seafood. int J. Environ. Res, Public Health 9, 807-820.

Nishiwaki-Matsushima, R., Ohta, T., Nishiwaki, S., Suganuma, M., Kohyama, K., Ishikawa, T., Carmichael, W., Fujiki, H., 1992. Liver tumor promotion by the cyanobacterial cyclic peptide toxin microcystin-LR. ]. Cancer Res. Clin. Oncol. $118,420-424$

Pane, L, Solisio, C., Lodi, A., Luigi Mariottini, G., Converti, A., 2008. Effect of extracts from Spirulina platensis bioaccumulating cadmium and zinc on L929 cells. Ecotoxicol. Environ. Saf. 70, 121-126.

Pearson, L., Mihali, T., Moffitt, M, Kellmann, R., Neilan, B, 2010. On the chemistry, toxicology and genetics of the cyanobacterial toxins, microcystin, nodularin, saxitoxin and cylindrospermopsin. Mar. Drugs 8, 1650-1680.

Petrus, M., Culerrier, R., Campistron, M., Barre, A., Rougé, P., 2010. First case report of anaphylaxis to spirulin: identification of phycocyanin as responsible allergen. Allergy 65, 924-925.

Preussel, K., Stüken. A., Wiedner, C., Chorus, I., Fastner, J., 2006. First report on cylindrospermopsin producing Aphanizomenon flos-aquae (Cyanobacteria) isolated from two German lakes. Toxicon 47, 156-162.

Rapala, I. Sivonen, K. Luukkainen, R., Niemelä, S., 1993. Anatoxin-a concentration in Anabaena and Aphanizomenon under different environmental conditions and comparison of growth by toxic and non-toxic Anabaena-strains - a laboratory study. J. Appl. Phycol. 5, 581-591.

Saker, M.L., Jungblut, A.-D., Neilan, B.A., Rawn, D.F.K., Vasconcelos, V.M., 2005. Detection of microcystin synthetase genes in health food supplements containing the freshwater cyanobacterium Aphanizomenon flos-aquae. Toxicon 46, 555-562.

Saker, M.L., Welker, M., Vasconcelos, V.M., 2007. Multiplex PCR for the detection of toxigenic cyanobacteria in dietary supplements produced for human consumption. Appl. Microbiol. Biotechnol. 73, 1136-1142.

Selwood, A.I. Holland, P.T., Wood, S.A, Smith, K.F., McNabb, P.S., 2007. Production of anatoxin-a and a novel biosynthetic precursor by the cyanobacterium Aphanizomenon issatschenkoi. Environ. Sci. Technol. 51, 506-510.

Sierosławska, A, Rymuszka, A. Kalinowska, R., Skowroński, T., Bownik, A, 'PawlikSkowrońska, B. 2010. Toxicity of cyanobacterial bloom in the eutrophic dam reservoir (Southeast Poland). Environ. Toxicol. Chem. 29, 556-560.

Smital, T., Terzic, S., Zaja, R., Senta, I., Pivcevic, B., Popovic, M., Mikac, I., Tollefsen, K. Thomas, K., Ahel, M., 2011. Assessment of toxicological profiles of the municipal wastewater effuents using chemical analyses and bioassays. Ecotoxicol, Environ. Saf. 74, 844-851.

Spoof, L., Vesterkvist, P., Lindholm, T. Meriluoto, J., 2003. Screening for cyanobacterial hepatotoxins, microcystins and nodularin in environmental water samples by reversed-phase liquid chromatography-electrospray ionisation mass spectrometry. J. Chromatogr. A 1020, 105 119.

Stüken, A., Jakobsen, K., 2010. The cylindrospermopsin gene cluster of Aphanizomenon sp. strain 10E6: organization and recombination. Microbiology 156, 2438-2451.

Vichi, S., Lavorini, P., Funari, E., Scardala, S., Testai, E., 2012. Contamination by Microcystis and microcystins of blue-green algae food supplements (BGAS) on the Italian market and possible risk for the exposed population. Food Chem. Toxicol. http://dx.doi.org/10.1016/j,fct.2012.09.029.

Vinogradova, T., Danaher, M., Baxter, A., Moloney, M., Victory, D., Haughey, S., 2011. Rapid surface plasmon resonance immunobiosensor assay for microcystin toxins in blue-green algae food supplements. Talanta 84, 638-643.

WHO, 1998. Cyanobacterial Toxins: Microcystin-LR, Guidelines for Drinking-water Quality. World Health Organization, Geneva, Pp. 95-110.

WHO, 1999. Toxic Cyanobacteria in Water: A Guide to their Public Health Consequences, Monitoring and Management. F \& FN Spon, London.

Yang, Y., Park, Y., Cassada, D., Snow, D., Rogers, D., Lee, J., 2011. In vitro and in vivo safety assessment of edible blue-green algae, Nostoc commume var. sphaeroides Kützing and Spindina plantensis. Food Chem. Toxicol, 49, 1560-1564.

Zhang, D., Hu, C., Wang, G., Li, D., Li, G., Liu, Y., 2012. Zebrafish neurotoxicity from aphantoxins-cyanobacterial paralytic shellfish poisons (PSPs) from Aphanizomenon flos-aquae DC-1. Environ. Toxicol. http://dx.doi.org/10.1002/tox.20714 